Article

\title{
Insight into Physicochemical, Rheological, and Antibacterial Properties of Chitosan Extracted from Antarctic krill: A Comparative Study
}

\author{
Yuan Yuan ${ }^{1}$, Luzhu Chen ${ }^{1}$, Wenzheng Shi ${ }^{1,2}$, Zhihe Wang ${ }^{1,3, *}$ and Hongcai Zhang ${ }^{1,2,3,4, *(D)}$ \\ 1 College of Food Science and Technology, Shanghai Ocean University, Shanghai 201306, China; \\ yyuan@shou.edu.cn (Y.Y.); lzchen@shou.edu.cn (L.C.); wzshi1@shou.edu.cn (W.S.) \\ 2 National R\&D Branch Center for Freshwater Aquatic Products Processing Technology (Shanghai), \\ Shanghai 201306, China \\ 3 School of Agriculture and Biology, Shanghai Jiao Tong University, Shanghai 200240, China \\ 4 State Key Laboratory for Pollution Control, School of Environmental Science and Engineering, \\ Tongji University, Shanghai 200092, China \\ * Correspondence: zhwang@shou.edu.cn (Z.W.); hczhang@shou.edu.cn (H.Z.)
}

Received: 26 July 2020; Accepted: 21 August 2020; Published: 7 September 2020

\begin{abstract}
In this work, physicochemical, rheological, and antibacterial properties of chitosan (CS) extracted from white shrimp (WS), giant river prawn (GP), and Antarctic krill (AK) were investigated. The results demonstrated that molecular weight (MW) of commercial chitosan (CCS), WSCS, GPCS, and AKCS were 1175.8, 2130.4, 1293.3, and $1109.3 \mathrm{kDa}$ with the degree of deacetylation (DDA) of $73.5,74.1,82.1$, and 75.9\%, respectively. Fourier transform infrared (FT-IR), X-ray diffraction (XRD), differential scanning calorimetry (DSC), and scanning electron microscope (SEM) were employed to study the structural differences of CS. Moreover, storage modulus $\left(G^{\prime}\right)$ and loss modulus ( $\left.G^{\prime \prime}\right)$ of AKCS were lower than that of WSCS and GPCS, respectively, but higher than that of CCS. Minimum inhibitory concentration (MIC) and minimum bacterial concentration (MBC) of CS against Escherichia coli and Staphylococcus aureus were investigated at concentration between 0.0125 and $1 \mathrm{mg} / \mathrm{mL}$. These results highlighted that AKCS with low viscoelastic properties had a potential application in food and pharmaceutical application.
\end{abstract}

Keywords: Antarctic krill; crustacean wastes; chitosan; rheology; antimicrobial activity

\section{Introduction}

With the development of aquaculture in recent years, approximately 6-8 million tons of crustacean wastes globally were produced worldwide every year [1]. It consists of $30-40 \%$ of proteins, $30-50 \%$ of $\mathrm{CaCO}_{3}$ and $\mathrm{Ca}_{3}\left(\mathrm{PO}_{4}\right)_{2}$, and 20-30\% of chitin [2]. However, crustacean wastes are abundantly discarded, leading to critical environmental pollution, as well as the wastes of valuable biomaterials. Antarctic krill (AK), as a key species in the Antarctic ecosystem [3], with the biomass of 342-356 million tons with high-quality useful components, are mostly used for aquatic feed with low commercial value [4]. Previous study has reported that AK contained 77.9-83.1\% moisture, $11.9-15.4 \%$ proteins, $0.4-2.6 \%$ lipids, and approximately $2 \%$ chitin [5]. Among them, protein and lipid have been commercially developed, and discarded AK shells could be utilized as a valuable source of chitosan (CS) [6].

CS, a deacetylated derivative of chitin, is recognized as one of the most abundant polysaccharides occurring in nature next to cellulose [7,8]. CS extracted from crustacean shell, squid, mushrooms, coral eggs, etc. could be widely used in several applications due to its excellent properties including biodegradability, biocompatibility, non-toxicity, and chelating ability of metal ions $[9,10]$. Three steps including deproteinization, demineralization, and removal of lipids and pigments were employed to 
prepare the chitin firstly [11]. Then, the conversion of chitin into CS was mostly conducted by strong alkaline deacetylation of chitin due to high efficiency. The preparation methods of CS using shrimp, crab, fishery, etc. has been reported in previous works [12-14]. Based on our best knowledge, no study has reported the preparation of AKCS where other crustaceans were also considered in detail.

In this work, CS was extracted from white shrimp (WS), giant river prawn (GP), and AK for comparing its physicochemical, structural, rheological, and antimicrobial properties. This study would provide a detailed exploration of CS extracted from crustacean shells, which was particularly beneficial to scale up their application in food and pharmaceuticals fields.

\section{Materials and Methods}

\subsection{Materials and Reagents}

WS and GP were purchased from No.157, Guzong Road, Nonggongshang supermarket in Shanghai, China. AK were caught in FAO 48.2 fishing area in March 2012, frozen and stored at $-20^{\circ} \mathrm{C}$. Commercial CS, $\mathrm{NaOH}(96 \%), \mathrm{HCl}(38 \%), \mathrm{K}_{2} \mathrm{MnO}_{4}(99.5 \%)$, oxalic acid $(99.5 \%), \mathrm{C}_{2} \mathrm{H}_{5} \mathrm{OH}(99.5 \%)$, nutrient agar, and trypticase soy broth (TSB) were obtained from Sinopharm Chemical Reagent Co. Ltd. (Shanghai, China).

\subsection{Preparation of WSCS, GPCS, and AKCS}

Three kinds of crustacean shells were thoroughly washed with deionized water and dried in an oven at $60^{\circ} \mathrm{C}$ overnight until a constant weight. The dried samples were completely smashed using ultrafine grinder (Cerendiptor MKCA 63, Masuko, Japan) and filtered with 200 mesh number sieve.

The accurately weighed samples were treated with $40 \% \mathrm{NaOH}(w / w)$ at $100{ }^{\circ} \mathrm{C}$ for $1 \mathrm{~h}$ to remove proteins, and then soaked in $5 \% \mathrm{HCl}(w / w)$ solution with rotation at $750 \mathrm{rpm}$ for $24 \mathrm{~h}$ at ambient temperature to remove $\mathrm{CaCO}_{3}$ and other minerals. Obtained chitin was decolored using $\left.10 \% \mathrm{v} v / \mathrm{v}\right)$ $\mathrm{H}_{2} \mathrm{O}_{2}$ at $100{ }^{\circ} \mathrm{C}$ for $5 \mathrm{~h}$, followed by washing using DI water and freeze-dried (LABCONCO 7,948,030 Co., USA) [11]. Finally, $2 \% \mathrm{~K}_{2} \mathrm{MnO}_{4}$ and $2 \%$ oxalic acid were employed at $60{ }^{\circ} \mathrm{C}$ for $1 \mathrm{~h}$ for the removal of pigments of chitin. Chitin was then deacetylated using $40 \%(w / v) \mathrm{NaOH}$. The mixtures were incubated in a $100{ }^{\circ} \mathrm{C}$ water bath for $1 \mathrm{~h}$ with constant stirring at $750 \mathrm{rpm}$ and then deacetylated again under the same conditions. The remaining CS solids were filtered and freeze-dried after adjusting a final $\mathrm{pH} 11$ using $4 \mathrm{~N} \mathrm{NaOH} \mathrm{[10].}$

\subsection{Physicochemical Properties of Prepared CS}

\subsubsection{Yield and Solubility}

Accurately weighted CS was dried in a vacuum drying oven at $30^{\circ} \mathrm{C}$ overnight until a constant weight for calculating its yields.

$$
\text { Yield }(\%)=\frac{\text { Weight of chitosan after drying }}{\text { Weight of added crustacean shells }} \times 100 \%
$$

The $0.1 \mathrm{~g}$ of CS was weighted and dissolved in $10 \mathrm{~mL}$ of $1 \%$ acetic acid at $30^{\circ} \mathrm{C}$ before centrifugation for $30 \mathrm{~min}$ [15]. The supernatant was removed and the sediment was dried at $60{ }^{\circ} \mathrm{C}$ overnight until a constant weight.

$$
\text { Solubility }(\%)=\frac{\text { Soluble chitosan weight }}{\text { Added chitosan weight }} \times 100 \%
$$

\subsubsection{Ash and Moisture Content}

The $1 \mathrm{~g}$ of CS was dried in a vacuum drying oven at $80^{\circ} \mathrm{C}$ for $4 \mathrm{~h}$ after carbonization for $2 \mathrm{~h}$ until constant weight. The $0.5 \mathrm{~g}$ of CS samples were dried at $105^{\circ} \mathrm{C}$ for $2 \mathrm{~h}$ until a constant weight. Moisture content of CS was calculated as follows. 


$$
\text { Moisture content }(\%)=\frac{\text { Wet weight }- \text { dry weight }}{\text { Wet weight }} \times 100 \%
$$

\subsubsection{Viscosity Average Molecular Weight (MW) and Degree of Deacetylation (DDA)}

Accurately weighed CS was dissolved in $0.5 \mathrm{M}$ acetic acid and $0.5 \mathrm{M}$ sodium acetate buffer at $25^{\circ} \mathrm{C}$ for the determination of intrinsic viscosity $[\eta]$. MW of CS was estimated using Mark-Houwink-Sakurada equation [16].

$$
[\eta]=\mathrm{K}[\mathrm{M} v]^{\mathrm{a}}
$$

where $\mathrm{K}=1.81 \times 10^{-3}$ and $\mathrm{a}=0.93$ are constants in Mark-Houwink-Sakurada equation.

The $0.1 \mathrm{~g}$ of CS was completely dissolved in $25 \mathrm{~mL}$ of $\mathrm{HCl}$ standard solution $(0.1 \mathrm{M})$ with help of ultrasound treatment. Then, $\mathrm{CS}$ solution was titrated with $0.1 \mathrm{M} \mathrm{NaOH}$ standard solution until the appearance from blue to green color using methyl red aniline blue as indicator. DDA of CS was calculated as followed [17]:

$$
\begin{gathered}
\mathrm{NH}_{2}(\%)=\frac{\left(C_{1} V_{1}-C_{2} V_{2}\right) \times 0.016}{G(100-W)} \times 100 \\
\operatorname{DDA}(\%)=\frac{N H_{2}}{9.94} \times 100
\end{gathered}
$$

where $C_{1}$ and $C_{2}$ are the concentration of $\mathrm{HCl}$ standard solution $(0.1008 \mathrm{~mol} / \mathrm{L})$ and $\mathrm{NaOH}$ standard solution, respectively. $V_{1}$ and $V_{2}$ are volume of $\mathrm{HCl}$ standard solution and consumed $\mathrm{NaOH}$ solution, respectively. The 9.94 is the theoretical amino content. $\mathrm{G}$ and $\mathrm{W}$ are weight and moisture content of CS, respectively.

\subsection{Scanning Electron Microscopy (SEM) Analysis of WSCS, GPCS, and AKCS}

SEM (Hitachi S-3400N, Tokyo, Japan) was used to observe the surface morphologies of WSCS, GPCS, and AKCS. The surface of CS was spread with a layer of gold before test. Surface images were taken at an acceleration voltage of $20 \mathrm{kV}$ and magnified to $20 \mu \mathrm{m}$.

\subsection{Structural Properties of WSCS, GPCS, and AKCS}

\subsubsection{Fourier Transform Infrared (FT-IR) Analysis}

Samples were blended with $\operatorname{KBr}(1: 99, w / w)$ and analyzed by FT-IR analyzer (Perkin Elmer Spectrum RXI, Naperville, IL, USA). Spectral scanning was taken in the wavelength regions between 4000 and $400 \mathrm{~cm}^{-1}$ at a resolution of $4 \mathrm{~cm}^{-1}$, and all samples were recorded at 16 scans. A background scanning was conducted before measurement and subtracted from sample spectra.

\subsubsection{Differential Scanning Calorimetry (DSC) Analysis}

Accurately weighed $5 \mathrm{mg}$ CS was placed into aluminum cup and left for equilibration at $2{ }^{\circ} \mathrm{C}$ for $2 \mathrm{~h}$, and empty aluminum cup was used as reference. All samples were heated to $500{ }^{\circ} \mathrm{C}$ using. DSC analyzer (model SDT Q600 Netzsch, Selb, Germany) at a heating rate of $10^{\circ} \mathrm{C} / \mathrm{min}$ and a gas flow of $23 \mathrm{~mL} / \mathrm{min}$. After ramp, a cooling ramp was started with a rate of $10^{\circ} \mathrm{C} / \mathrm{min}$ down to $2{ }^{\circ} \mathrm{C}$ and left for equilibration for $2 \mathrm{~h}$.

\subsubsection{X-ray Diffraction (XRD) Analysis}

XRD analysis was recorded at a scan rate of $10^{\circ} / \mathrm{min}$ with the scan angle from 5 to $80^{\circ}$ using D8 advance (Bruker, Karlsruhe, German) (30 kV and $40 \mathrm{~mA})$. Crystallinity index (CrI) was calculated using the following formula [18]:

$$
\operatorname{CrI}(\%)=\frac{\mathrm{I}_{100}-I_{a m}}{\mathrm{I}_{100}} \times 100 \%
$$


where $\mathrm{I}_{110}$ is the maximum intensity at $20^{\circ}$ and $I_{a m}$ is the maximum intensity of amorphous diffraction at $16^{\circ}$.

\subsection{Rheological Properties of WSCS, GPCS, and AKCS}

CS solution ( $0.5 \%)$ was completely dissolved in $1 \%$ aqueous acetic acid $(w / v)$ and configured to reduce impurities and air bubbles at 12,000 rpm for $5 \mathrm{~min}$. Rheological properties of CS were measured from 0.01 to $1000 \mathrm{1} / \mathrm{s}$ at $20^{\circ} \mathrm{C}$ using rheometer (MCR301 Anton paar, Shanghai, China). To further investigate the storage modulus $\left(G^{\prime}\right)$ and loss modulus $\left(G^{\prime \prime}\right)$, a frequency sweep was determined from 0.1 to $5 \mathrm{~Hz}$ with the strain of $2 \%$ at $20{ }^{\circ} \mathrm{C}$. Parameters of $\mathrm{G}^{\prime}$ and $\mathrm{G}^{\prime \prime}$ as a function of angular frequency were directly obtained from computer software (Rheological Advantage Data Analysis Program, TA Instruments, New Castle, DE, USA).

Experimental data were fitted by power-law equations:

$$
\begin{aligned}
G^{\prime} & =K^{\prime} \omega^{n \prime} \\
G^{\prime \prime} & =K^{\prime \prime} \omega^{n^{\prime \prime}}
\end{aligned}
$$

where $G^{\prime}$ is storage modulus (Pa), $G^{\prime \prime}$ is loss modulus (Pa), $K^{\prime}, K^{\prime \prime}, \omega^{n^{\prime}}$, and $\omega^{n^{\prime \prime}}$ are constants [19].

For steady shear measurements, shear rates ranging from 1 to $100 \mathrm{~s}^{-1}$ were used with shear time of $2 \mathrm{~min}$. The relationship between shear stress and shear rate was recorded at $25^{\circ} \mathrm{C}$. Experimental data were fitted by a Herschel-Bulkley's model [19]:

$$
\tau=\tau_{0}+K \varepsilon^{n}
$$

where $\mathrm{s}$ is shear stress $(\mathrm{Pa}), \tau_{0}$ is yield stress $(\mathrm{Pa}), \mathrm{K}$ is consistency coefficient, $\varepsilon$ is shear rate $\left(\mathrm{s}^{-1}\right)$, and $n$ is flow behavior index.

\subsection{Antimicrobial Activity of WSCS, GPCS, and AKCS}

Minimum inhibitory concentration (MIC) and minimum bacterial concentration (MBC) were used to measure the antibacterial activity of CS. MIC was determined by a turbidimetric method based on previous report [20]. The $1,0.5,0.25,0.125$, and $0.0625 \mathrm{mg} / \mathrm{mL}$ of CS solutions were prepared by double-dilution method. Escherichia coli $\left(\mathrm{G}^{-}\right)$and Staphylococcus aureus $\left(\mathrm{G}^{+}\right)$were cultured in TSB medium and diluted to about $10^{7} \mathrm{CFU}$.

All sample solutions were accurately quantified and added into DI water. For the first tube, $5.0 \mathrm{~mL}$ CS solutions $(1 \mathrm{mg} / \mathrm{mL})$ was added, respectively. After mixing, $5.0 \mathrm{~mL}$ of mixtures was transferred to the second tube, and similar transformation was repeated. Hence, each tube contained a test sample solution with half of the concentration of the previous one. The tubes were inoculated with $50 \mu \mathrm{L}$ of freshly prepared bacteria suspension under aseptic conditions. All samples were adjusted to $\mathrm{pH} 4.5$ with $0.1 \mathrm{M} \mathrm{NaOH}$ for equal comparisons and incubated at $35^{\circ} \mathrm{C}$ for $24 \mathrm{~h}$ to evaluate MIC subsequently. MBC is defined as the concentration producing a $99.9 \%$ reduction of colony number in the initial inoculum by assaying the live organisms in those tubes from the MIC test that showed no growth.

\subsection{Data Analysis}

One-way ANOVA analysis was carried out to determine the significant differences using the SPSS program (SPSS 24.0, IBM SPSS Institute, Inc., Chicago, IL, USA). The pictures were processed using Origin 9.0 (Origin Lab Inc., Northampton, MA, USA). Data differences were considered to be statistically significant when $p<0.05$. All data were conducted at least in triplicate and reported as mean values \pm standard errors. 


\section{Results and Discussion}

\subsection{Physicochemical Analysis of WSCS, GPCS, and AKCS}

\subsubsection{Yields and Solubility}

As shown in Figure 1, yields of WSCS, GPCS, and AKCS were $12.6 \pm 0.44,8.9 \pm 0.46$, and $14.1 \pm 0.56 \%$, respectively. The results indicated that AK was a desirable CS source. Solubility of CCS, WSCS, GPCS, and AKCS was $99.3 \pm 0.26,95.0 \pm 0.15,89.2 \pm 0.32$, and $82.8 \pm 1.29 \%$, respectively (Figure 1), indicating that CC has the highest solubility. Solubility of CCS mainly depended on the reaction temperature during deacetylation [21]. Hossain and Iqbal [22] found that the solubility of CS could be affected by several critical factors including deacetylation reaction time, temperature, alkali concentration, and particle size. Moreover, solubility of CS could also be affected by MW and biological origins of CS [23].
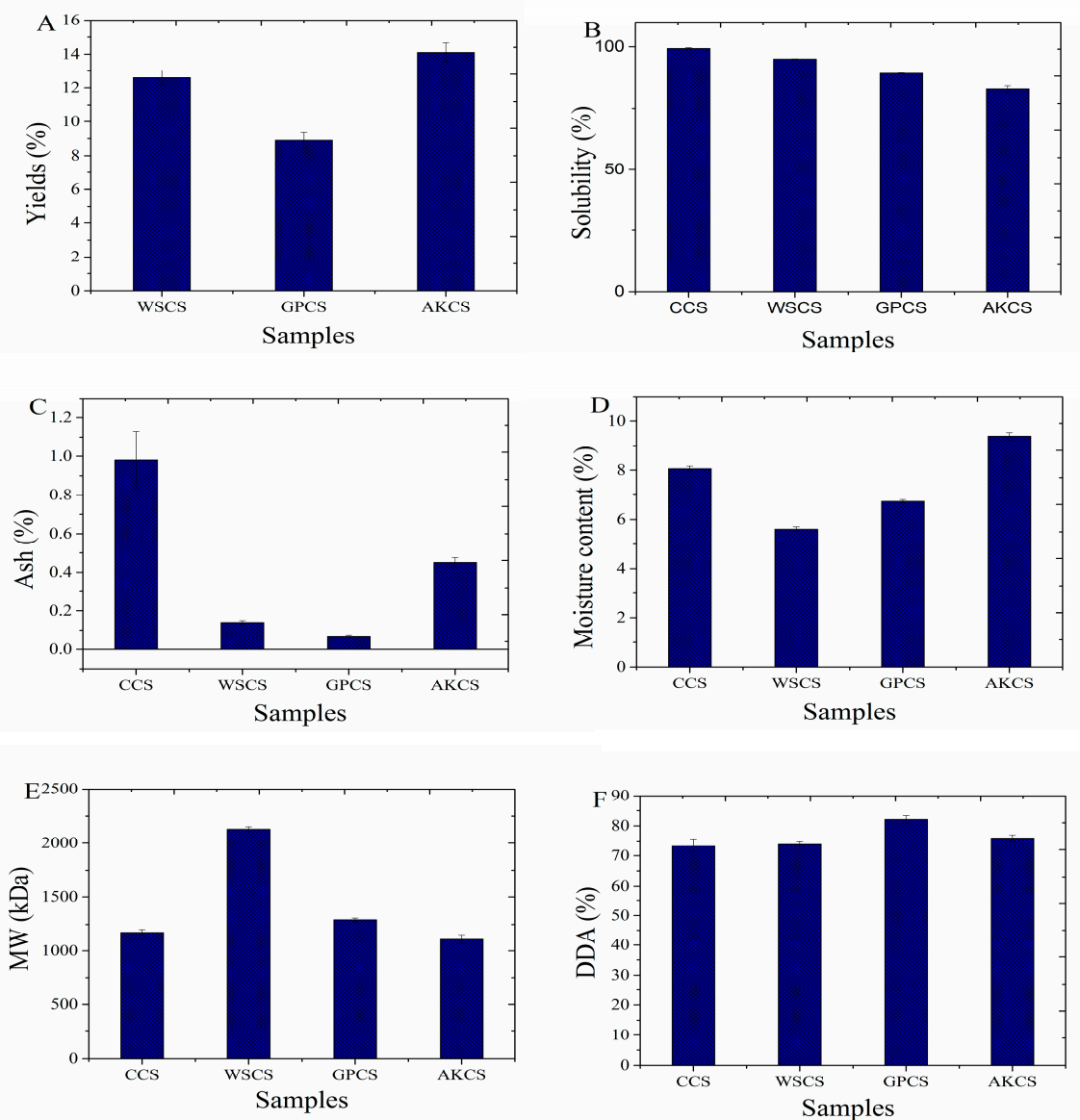

Figure 1. Yield (A), solubility (B), ash (C), moisture content (D), MW (E), and degree of deacetylation (DDA) (F) of CCS, WSCS, GPCS, and AKCS. CCS: commercial chitosan; WSCS: white shrimp chitosan; GPCS: giant river prawn chitosan; AKCS: Antarctic krill chitosan; MW: molecular weight.

\subsubsection{Ash and Moisture Content}

Ash contents of CCS, WSCS, GPCS, and AKCS were $0.98 \pm 0.01,0.14 \pm 0.01,0.07 \pm 0.006$, and $0.45 \pm 0.02 \%$, respectively. It was indicated that GPCS has the lowest ash content, which was related to the DDA and origins of CS. Ash content of CCS is an important parameter affecting its solubility, viscosity, and other physicochemical characteristics [12]. Moisture of CCS, WSCS, GPCS, and AKCS reached $8.06 \pm 0.11,5.61 \pm 0.10,6.73 \pm 0.073$, and $9.39 \pm 0.15 \%$, respectively (Figure 1). Moisture contents were also one of the significant properties to evaluate the characteristics of CS 
because water molecules could be adsorbed on the polymeric chains and acted as a plasticizer effect on thermal stability of CS [12]. Moreover, moisture contents of CS were also closely related to the purity of CS influenced by its origins [23].

\subsubsection{MW and DDA}

MW of CCS, WSCS, GPCS, and AKCS was $1175.8 \pm 27.31,2130.4 \pm 23.35,1293.3 \pm 17.16$, and $1109.3 \pm 35.62 \mathrm{kDa}$, respectively (Figure 1). Previous studies reported that low MW CS had better antiseptic [24] and anticancer [25] ability than higher MW one. The main factors of influencing MW of CS consisted of extraction time, temperature, reagent concentration of CS, etc. [26]. In addition, Younes also indicated that MW of CS varied with its origins and the residual aggregates in the matrix [27].

DDA of CCS, WSCS, GPCS, and AKCS was $73.5 \pm 2.13,74.1 \pm 0.85,82.1 \pm 1.28$, and $75.9 \pm 1.07 \%$, respectively. It is well-known that DDA influences the physical, chemical, and biological properties of CS including electrostatic characteristics, biodegradability, self-aggregation, adsorption properties, and chelating ability of metal ions [28]. DDA, representing the removal of acetyl group of chitin, mainly determines the content of free amino groups in the polysaccharides, which was affected by crustacean species and preparation process [29]. Moreover, alkali concentration was also recognized as an important factor to influence DDA value [30]. During DDA, preferred $60 \%$ of $\mathrm{NaOH}(w / w)$ concentration and $12 \mathrm{~h}$ of reaction time were the optimal reaction conditions for removing the acetyl groups according to previous reports [31,32].

\subsection{SEM Observation}

SEM images of CCS, WSCS, GPCS, and AKCS showed in Figure 2 had obvious differences. WSCS and AKCS showed rougher surface morphology and ridges than CCS and GPCS (Figure 2B,D). Moreover, AKCS displayed smooth microfibrillar crystalline structure and layer structure largely intact (Figure 2D). It was found that surface structure of WSCS was more compact than that of AKCS. The micrograph of GPCS showed granular bulge and porosity structure in Figure 2C, but smooth and flat surface for CCS (Figure 2A). It could be explained that the four kind CS has different origins.
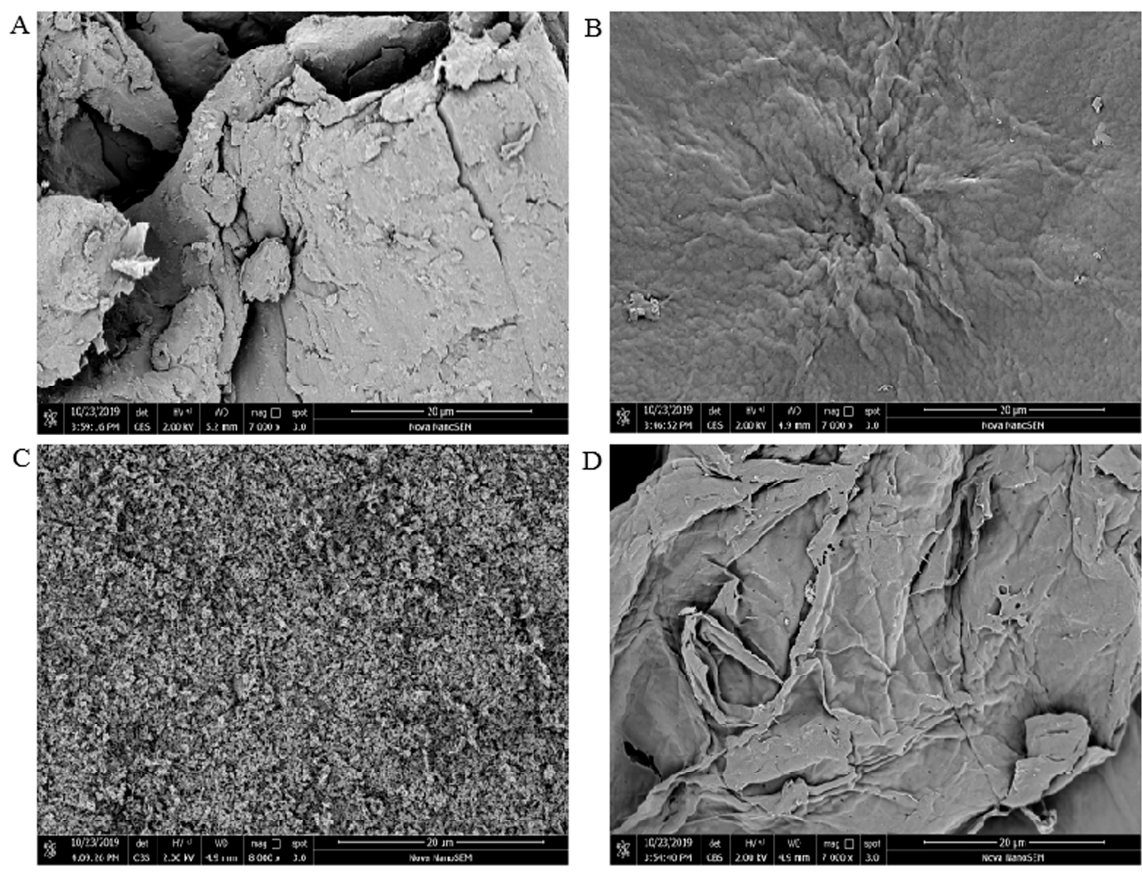

Figure 2. SEM images $(20 \mu \mathrm{m})$ of CCS (A), WSCS (B), GPCS (C), and AKCS (D). CCS: commercial chitosan; WSCS: white shrimp chitosan; GPCS: giant river prawn chitosan; AKCS: Antarctic krill chitosan. 


\subsection{Structural Analysis of CCS, WSCS, GPCS, and AKCS}

\subsubsection{FT-IR Analysis}

Peaks of CS from crustaceans shells at 3438, 2919, 1659, 1593, 1420, and $1080 \mathrm{~cm}^{-1}$ represented $-\mathrm{OH},-\mathrm{CH}$, amide $\mathrm{I}, \mathrm{NH}_{2}$ bending vibration, $-\mathrm{OH}$ and $-\mathrm{CH}$, and $-\mathrm{C}-\mathrm{O}$ stretching vibrations, respectively (Figure 3) [11,33,34]. Furthermore, the specific bands of -C-O and -C-O-C stretching absorbing between 1052 and $1030 \mathrm{~cm}^{-1}$ were observed for all CS. All CS showed the similar FT-IR curves, and the absorbance of peaks around $1593 \mathrm{~cm}^{-1}$ represented the $-\mathrm{NH}_{2}$ bending vibration in amino group, which indicated the difference of DDA among CS [35]; the higher the peak was, the higher DDA was, which was consistent with DDA results (Figure 1).

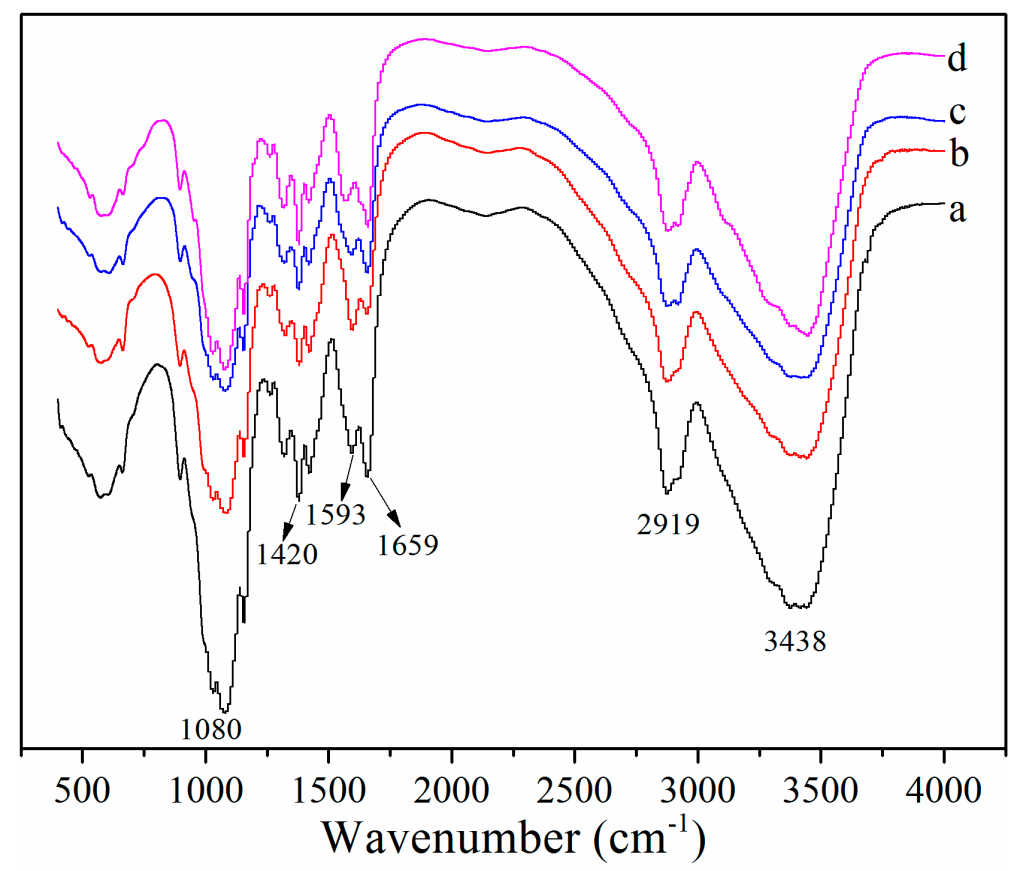

Figure 3. FT-IR analysis of CCS (a), WSCS (b), GPCS (c), and AKCS (d). CCS: commercial chitosan; WSCS: white shrimp chitosan; GPCS: giant river prawn chitosan; AKCS: Antarctic krill chitosan.

\subsubsection{DSC Analysis}

DSC curves of CCS, WSCS, GPCS, and AKCS are presented in Figure 4A. All samples showed the endothermic peak at $100-110{ }^{\circ} \mathrm{C}$, attributing to the evaporation of absorbed and bound water [36]. The reason why WSCS did not display the endothermic peak was probably due to the lower moisture content showed in Figure 1. All samples had similar exothermic peak appearing around $300-310{ }^{\circ} \mathrm{C}$ due to the glass transition followed by decomposition [37]; among them, the exothermic peak maximum of GPCS was slightly shifted rightwards, it might be explained that moisture (entrapped inside CS structure) evaporation from amorphous structure of GPCS, as well as the availability of less polar $-\mathrm{NH}_{2}$ groups [38].

Thermoanalytic parameters obtained from DSC curves are summarized in Table 1. The onset temperatures $\left(\mathrm{T}_{\mathrm{O}}\right)$ were in the range of $276.75-2293.06{ }^{\circ} \mathrm{C}$ with the descending order of GPCS $\approx$ AKCS $<$ WSCS $<$ CCS. Thus, GPCS and AKCS exhibited higher thermal stability than that of WSCS and CCS. The slight discrepancy in the peak temperatures $\left(T_{p}\right)$ might be due to the diversity of CS origins and the different preparation methods applied. The completion temperatures $\left(\mathrm{T}_{\mathrm{C}}\right)$ were in the range of $353.27-371.54{ }^{\circ} \mathrm{C}$ with the descending order of CCS $<$ WSCS $<$ GPCS $<$ AKCS. The decomposition enthalpies $(\Delta \mathrm{H})$ of CCS, WSCS, GPCS, and AKCS were 235.07, 193.00, 154.09, 
and $145.08 \mathrm{~J} / \mathrm{g}$, respectively [39]. The higher the $\Delta \mathrm{H}$ was, the lower the thermal stability was, indicating GPCS has the lowest thermal stability [14].
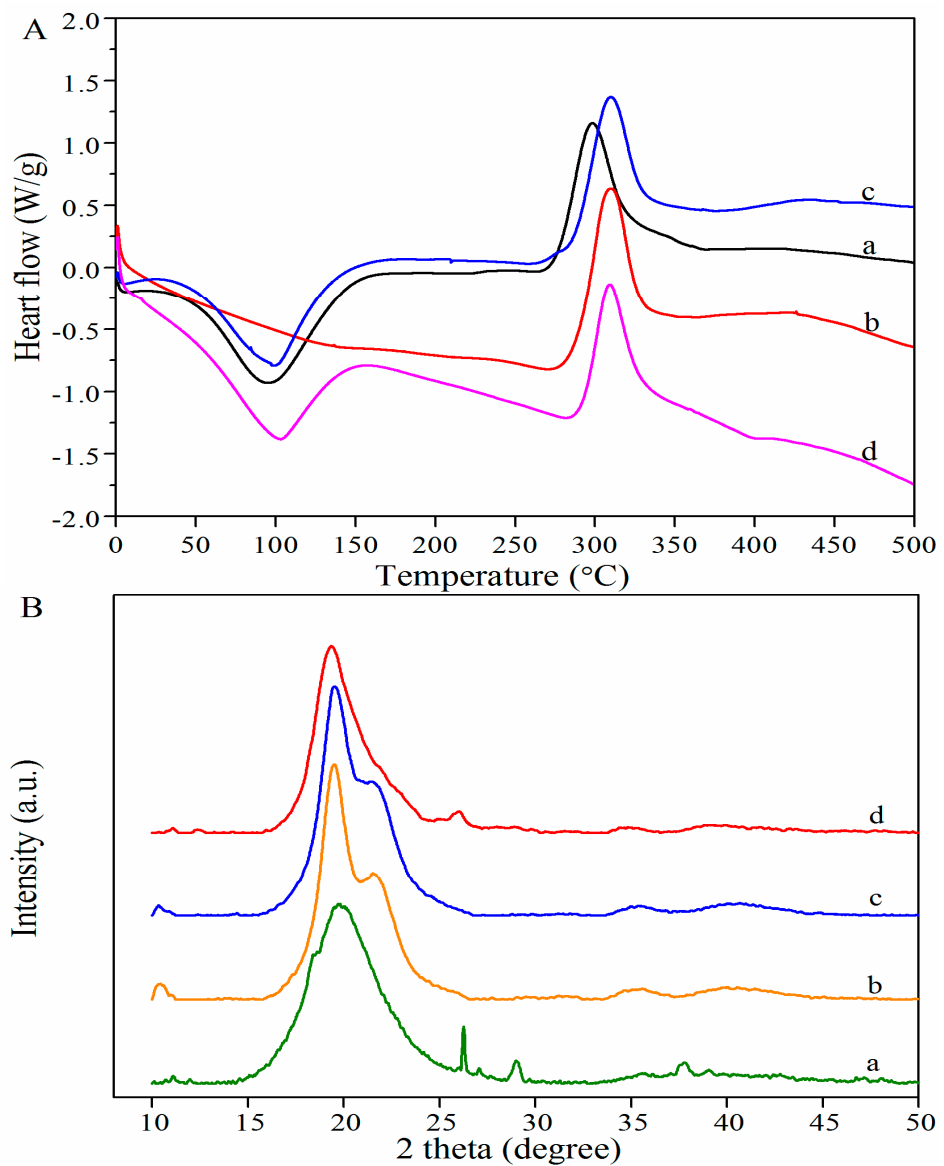

Figure 4. DSC (A) and XRD (B) analysis of CCS (a), WSCS (b), GPCS (c), and AKCS (d). CCS: commercial chitosan; WSCS: white shrimp chitosan; GPCS: giant river prawn chitosan; AKCS: Antarctic krill chitosan.

Table 1. Differential scanning calorimetry (DSC) parameters of CCS, WSCS, GPCS, and AKCS.

\begin{tabular}{|c|c|c|c|c|c|}
\hline \multirow{2}{*}{ Samples } & \multicolumn{4}{|c|}{ DSC } & \multirow{2}{*}{$\begin{array}{c}\text { XRD } \\
\text { CrI (\%) }\end{array}$} \\
\hline & $\mathrm{T}_{\mathrm{o}}\left({ }^{\circ} \mathrm{C}\right)^{++}$ & $\mathrm{T}_{\mathrm{p}}\left({ }^{\circ} \mathrm{C}\right)$ & $\mathrm{T}_{\mathrm{c}}\left({ }^{\circ} \mathrm{C}\right)$ & $\Delta \mathrm{H}(\mathrm{J} / \mathrm{g})$ & \\
\hline $\mathrm{CCS}^{+}$ & $276.75 \pm 6.57^{\mathrm{a}+++}$ & $298.39 \pm 4.68^{\mathrm{a}}$ & $371.54 \pm 10.24^{\mathrm{a}, \mathrm{b}}$ & $235.07 \pm 5.38^{c}$ & $89.86 \pm 1.31^{b}$ \\
\hline WSCS & $288.20 \pm 6.45^{\mathrm{a}}$ & $309.60 \pm 5.32^{\mathrm{a}}$ & $359.62 \pm 8.35^{\mathrm{a}}$ & $193.00 \pm 6.24^{b}$ & $83.25 \pm 1.54^{\mathrm{a}}$ \\
\hline GPCS & $293.06 \pm 8.24^{\mathrm{a}}$ & $309.96 \pm 7.38^{\mathrm{a}}$ & $355.24 \pm 9.15^{\mathrm{a}}$ & $154.09 \pm 7.05^{\mathrm{a}, \mathrm{b}}$ & $84.27 \pm 1.86^{\mathrm{a}}$ \\
\hline AKCS & $292.51 \pm 7.39^{a}$ & $309.14 \pm 9.05^{\mathrm{a}}$ & $353.27 \pm 7.68^{a}$ & $145.08 \pm 5.39^{a}$ & $90.39 \pm 1.44^{b}$ \\
\hline
\end{tabular}

+ CCS: commercial chitosan; WSCS: white shrimp chitosan; GPCS: giant river prawn chitosan; AKCS: Antarctic krill chitosan. ${ }^{++}$Different superscript letters $(\mathrm{a}-\mathrm{c})$ in the same column indicate a significant difference $(p<0.05)$. ${ }^{+++} \mathrm{T}_{\mathrm{o}}$ : onset temperature; $\mathrm{T}_{\mathrm{p}}$ : peak temperature; $\mathrm{T}_{\mathrm{c}}$ : completion temperature; $\Delta \mathrm{H}$ : peak enthalpy $(\mathrm{J} / \mathrm{g}$, dry weight); CrI: crystallinity index.

\subsubsection{XRD Analysis}

XRD spectra of CS present characteristic peaks at $20^{\circ}$, which was in agreement with previous reports (Figure 4B). Jung, Kuk, Kim, and Park also reported the one characteristic crystalline reflection at $19.9^{\circ}$ for crustacean CS [40]. CCS has several small reflection peaks compared to others because of high ash content [10]. CrI of CS mainly depended on several factors including origins, preparation conditions, DDA, etc. CrI of CCS, WSCS, GPCS, and AKCS reached 89.86, 83.25, 84.27, and 90.39\%, respectively (Table 2), indicating AKCS with high CrI was related to crystal II in CS structure [41,42]. 
Table 2. MIC and MBC of four kinds of chitosan.

\begin{tabular}{ccccc}
\hline \multirow{2}{*}{ Samples } & \multicolumn{2}{c}{ MIC $(\mathbf{m g} / \mathbf{m L})$} & \multicolumn{2}{c}{ MBC $(\mathbf{m g} / \mathbf{m L})$} \\
\cline { 2 - 5 } & E. coli & S. aureus & coli & S. aureus \\
\hline CCS & 0.5 & 0.25 & 1 & 0.25 \\
WSCS & 0.125 & 0.125 & 0.25 & 0.125 \\
GPCS & 0.0625 & 0.0625 & 0.125 & 0.125 \\
AKCS & 0.25 & 0.125 & 0.5 & 0.125 \\
\hline
\end{tabular}

CCS: commercial chitosan; WSCS: white shrimp chitosan; GPCS: giant river prawn chitosan; AKC: Antarctic krill chitosan. MIC and MBC represented minimal inhibitory concentration and minimum bactericidal concentration, respectively.

\subsection{Rheological Measurements of CCS, WSCS, GPCS, and AKCS}

A strain sweep was carried out at a constant frequency $(1 \mathrm{~Hz})$ under $20^{\circ} \mathrm{C}$ to investigate the relationship between modulus and strain or frequency. The $G^{\prime}$ and $G^{\prime \prime}$ are demonstrated in Figure 5A,B, respectively. Both $G^{\prime}$ and $G^{\prime \prime}$ values of WSCS gradually increased in a frequency range from 0.1 to $5 \mathrm{~Hz}$ for forming a more compact matrix structure. The $\mathrm{G}^{\prime}$ value was greater than $\mathrm{G}^{\prime \prime}$, leading to low mechanical strength and high viscosity strength $[43,44]$. The $G^{\prime}$ and $G^{\prime \prime}$ of WCCS were higher than other CS, which indicated the higher viscosity and more stability than others. The order of $\mathrm{G}^{\prime}$ and $\mathrm{G}^{\prime \prime}$ were the ascending order of WCCS > GPCS > AKCS > CCS [44]. Moreover, $\mathrm{G}^{\prime}$ value decreased whereas the viscous character increased $\left(G^{\prime \prime}\right)$, avoiding the crossover of the moduli throughout the frequency range studied.
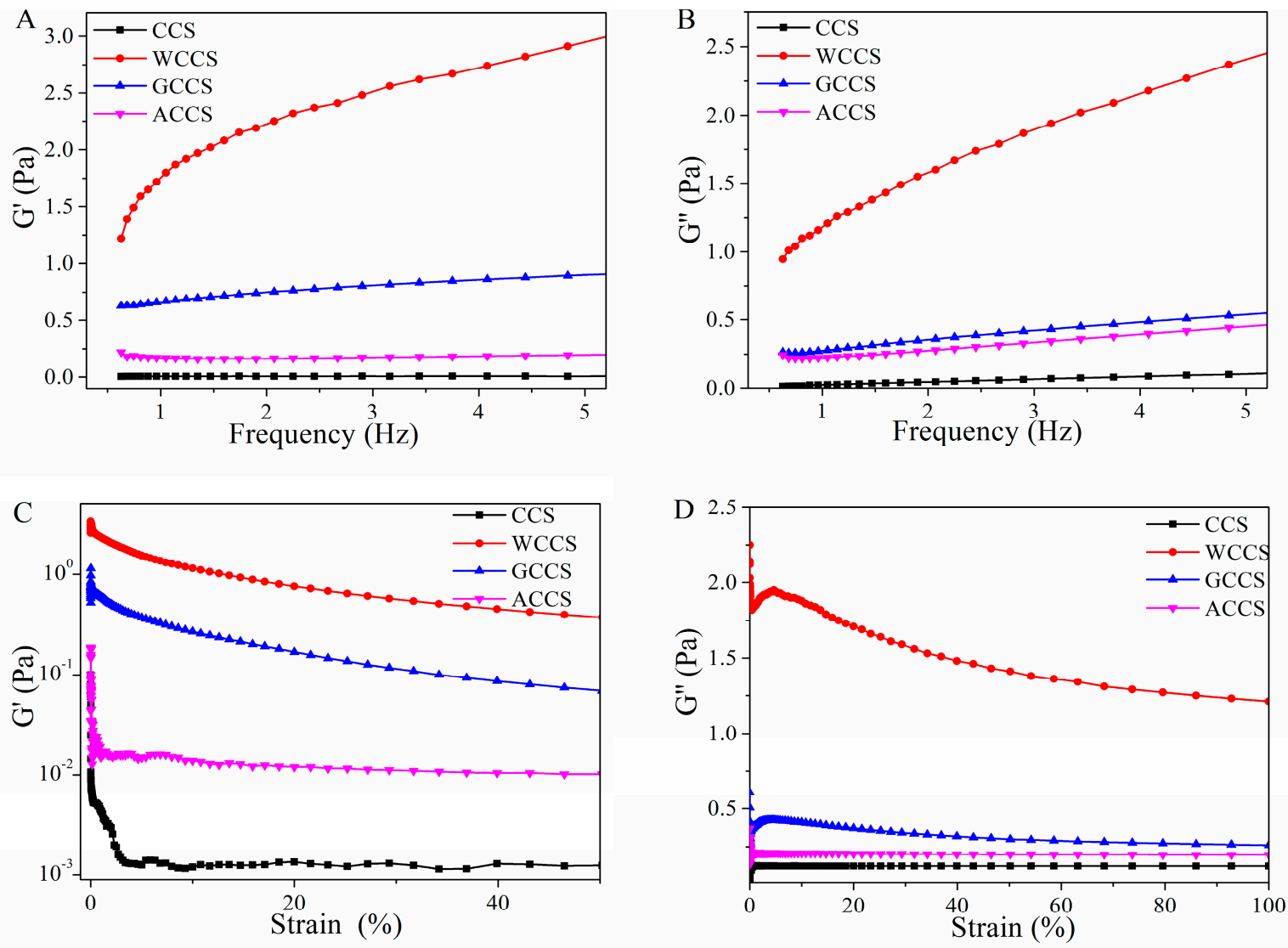

Figure 5. Storage modulus $G^{\prime}(\mathbf{A}, \mathbf{C})$ and loss modulus $G^{\prime \prime}(\mathbf{B}, \mathbf{D})$ of CCS, WSCS, GPCS, and AKCS vs. frequency (strain). CCS: commercial chitosan; WSCS: white shrimp chitosan; GPCS: giant river prawn chitosan; AKCS: Antarctic krill chitosan. 
The apparent viscosity of non-Newtonian fluids decreased with increasing shear rate in a range of $0.001-1000 \mathrm{~s}^{-1}$ at $20^{\circ} \mathrm{C}$ (Figure 6). The graph indicated a drastic decrease in viscosity of CS at the beginning, validating the shear-thinning behavior and pseudo-plastic fluid of CS. GPCS with linear molecules and rigidity showed the most stable viscosity [45], followed by AKCS, CCS, and WCCS. It was found that viscosity of CS might be due to intertwining of polymer chains, which revealed the entanglement density affected by MW and resulted in a decrease of apparent viscosity [46]. In addition, the viscosity of CS was also influenced by its conformation and structural flexibility and linear molecules [47].
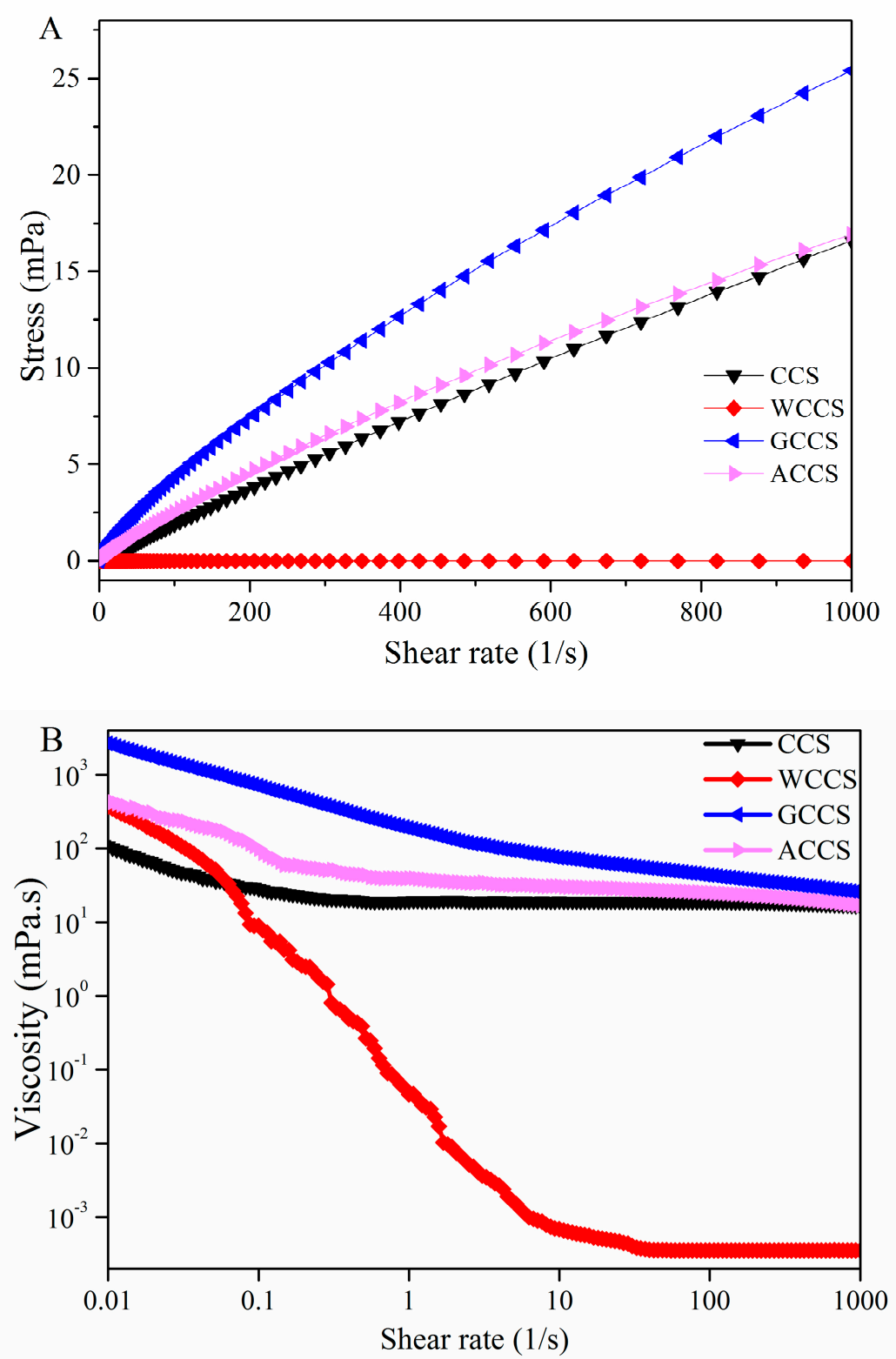

Figure 6. Stress (A) and viscosity (B) vs. shear rate (1/s) of CCS, WSCS, GPCS, and AKCS solutions. CCS: commercial chitosan; WSCS: white shrimp chitosan; GPCS: giant river prawn chitosan; AKCS: Antarctic krill chitosan.

\subsection{Antimicrobial Activity}

MIC and MBC of CCS, WSCS, GPCS, and AKCS against E. coli and S. aureus are presented in Table 2. Colony growth of CCS, WSCS, GPCS, and AKCS solutions for MBC measurement is shown in Figure 7. The order of MIC ranking for $E$. coli was $\mathrm{GC}<\mathrm{WS}<\mathrm{AC}<\mathrm{CC}$, and $\mathrm{GC}<\mathrm{WS} \approx \mathrm{AC}<\mathrm{CC}$ for 
S. aureus. GPCS has the lowest MIC $(0.0625 \mathrm{mg} / \mathrm{mL})$ and MBC $(0.125 \mathrm{mg} / \mathrm{mL})$, indicating its superior antibacterial activities against $E$. coli and $S$. aureus. The reason why GPCS exhibited the higher MIC and MBC was because of its high DDA and low MW [48], which was consistent with physicochemical parameters (Figure 1). WSCS, GPCS, and AKCS had the same MBC, lower than CCC against $S$. aureus. The antimicrobial activity of CS affected by several factors including MW, DDA\%, microorganism species, ionic strength, and $\mathrm{pH}$ of matrix [49]. In general, antibacterial activity of $\mathrm{CS}$ was more effective against $E$. coli than $S$. aureus, which was in accordance with previous studies [50,51].

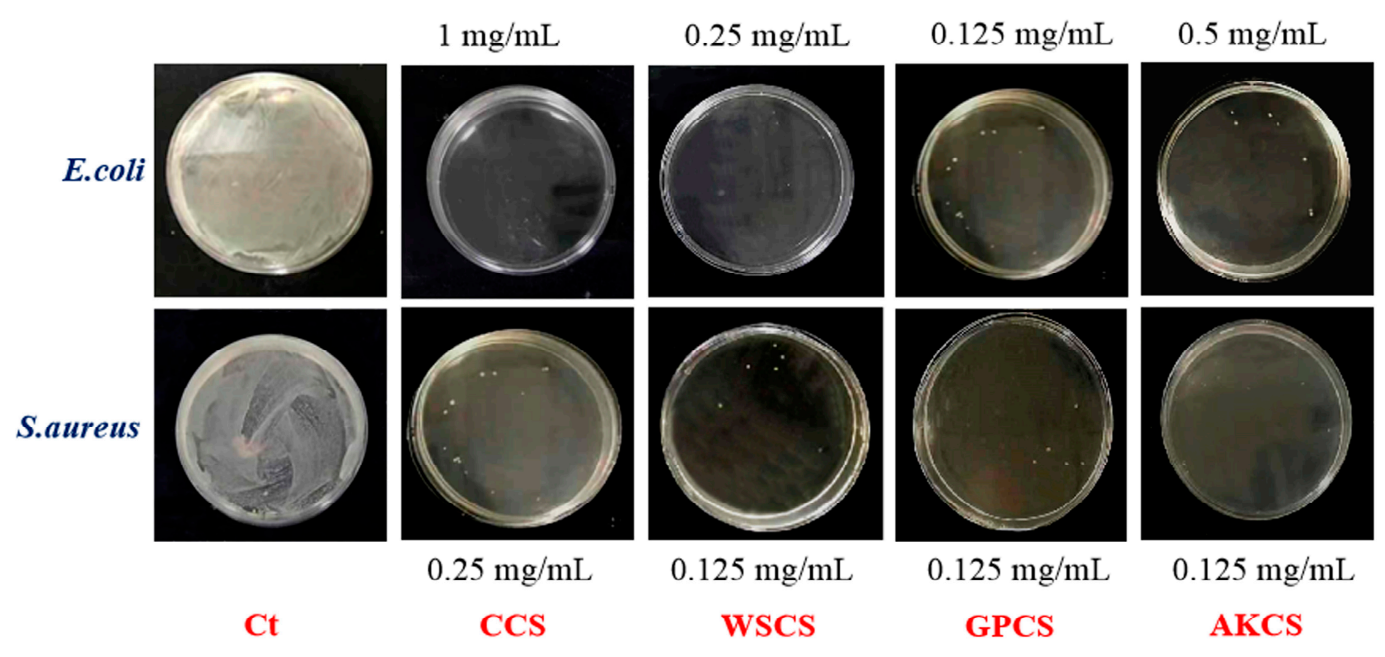

Figure 7. Colony growth of CCS, WSCS, GPCS, and AKCS solutions for MBC. Ct: controls; CCS: commercial chitosan; WSCS: white shrimp chitosan; GPCS: giant river prawn chitosan; AKCS: Antarctic krill chitosan.

Antibacterial mechanisms of CS have been reported in several published literatures. (1) Cationic chains of CS polymer are attached to the outer membrane of $\mathrm{G}^{+}$bacteria through more effective electrostatic interaction than $\mathrm{G}^{-}$did, thus rendering the excellent antibacterial activity, (2) CS could penetrate the bacterial cell wall, inhibiting the synthesis of mRNA and DNA transcription [52], (3) CS could play a key role on the uptake and secretion of substrates for inhibiting enzyme activity and killing the bacteria $[53,54]$.

\section{Conclusions}

In this work, CS was extracted from WS, GP, and AK for investigating its physicochemical, rheological, and antibacterial properties. DDA of CCS, WSCS, GPCS, and AKCS were 73.5, 74.1, 82.1, and $75.9 \%$ with MW of $1175.8,2130.4,1293.3$, and $1109.3 \mathrm{kDa}$, respectively. Compared with WSCS and GPCS, AKCS had low $\mathrm{G}^{\prime}$ and $\mathrm{G}^{\prime \prime}$, but poor antibacterial activity. All CS exhibited the viscoelastic properties, among them, WSCS had higher viscosity and more stability than others based on the results of rheological measurements. MIC and MBC results indicated that GPCS presented the best bacterial activity against $E$. coli and $S$. aureus. This study will provide a new idea for expanding the utilization of $\mathrm{AK}$ and other crustacean wastes in the near further.

Author Contributions: Design, conceptualization: Y.Y. and H.Z.; manuscript writing and proofreading: Y.Y. and H.Z.; experimental work, data analysis and interpretation: L.C., H.Z., W.S. and Z.W. All authors have read and agreed to the published version of the manuscript.

Funding: This work was financially supported by the Natural Science Foundation of Shanghai Municipal (19ZR1422900) and the National Natural Science Foundation of China (No: 41776185).

Acknowledgments: This work was financially supported by the Natural Science Foundation of Shanghai Municipal (19ZR1422900) and the National Natural Science Foundation of China (No: 41776185).

Conflicts of Interest: The authors declare no conflict of interest. 


\section{Abbreviations}

CS: chitosan; CCS: commercial chitosan; WS: white shrimp; GP: giant river prawn; AK: Antarctic krill; MW: molecular weight; DDA: degree of deacetylation; CrI: crystallinity index; FT-IR: Fourier transform infrared; XRD: X-ray diffraction; DSC: differential scanning calorimetry; SEM: scanning electron microscope; $\mathrm{T}_{\mathrm{o}}$ : onset temperature; $\mathrm{T}_{\mathrm{p}}$ : peak temperature; $\mathrm{T}_{\mathrm{c}}$ : completion temperature; $\Delta \mathrm{H}$ : peak enthalpy $\left(\mathrm{J} / \mathrm{g}\right.$, dry weight); $\mathrm{G}^{\prime}$ : storage modulus; $G^{\prime \prime}$ : loss modulus; MIC: minimum inhibitory concentration; MBC: minimum bacterial concentration.

\section{References}

1. Alfaro-Montoya, J.; Braga, A.L.; Umaña-Castro, R. Research frontiers in penaeid shrimp reproduction: Future trends to improve commercial production. Aquaculture 2019, 503, 70-87. [CrossRef]

2. Kumari, S.; Rath, P.; Kumar, A.S.H.; Tiwari, T. Extraction and characterization of chitin and chitosan from fishery waste by chemical method. Environ. Technol. Innov. 2015, 3, 77-85. [CrossRef]

3. Sun, J.; Mao, X. An environmental friendly process for Antarctic krill (Euphausia superba) utilization using fermentation technology. J. Clean. Prod. 2016, 127, 618-623. [CrossRef]

4. Floreto, E.; Brown, P.; Bayer, R. The effects of krill hydrolysate-supplemented soya-bean based diets on the growth, colouration, amino and fatty acid profiles of juvenile American lobster, Homarus americanus. Aquac. Nutr. 2001, 7, 33-43. [CrossRef]

5. Mathiesen, A.M. The state of world fisheries and aquaculture, 2012. Choice Rev. Online 2013, 50, 50. [CrossRef]

6. Gigliotti, J.C.; Davenport, M.P.; Beamer, S.K.; Tou, J.C.; Jaczynski, J. Extraction and characterisation of lipids from Antarctic krill (Euphausia superba). Food Chem. 2011, 125, 1028-1036. [CrossRef]

7. Yuan, G.; Li, W.; Pan, Y.; Wang, C.; Chen, H. Shrimp shell wastes: Optimization of peptide hydrolysis and peptide inhibition of $\alpha$-amylase. Food Biosci. 2018, 25, 52-60. [CrossRef]

8. Davies, G.J.G.; Knight, D.P.; Vollrath, F. Chitin in the silk gland ducts of the spider nephila edulis and the silkworm bombyx mori. PLoS ONE 2013, 8, e73225. [CrossRef]

9. Knidri, H.; Belaabed, R.; Addaou, A.; Laajeb, A.; Lahsini, A. Extraction, chemical modification and characterization of chitin and chitosan. Int. J. Boil. Macromol. 2018, 120, 1181-1189. [CrossRef]

10. Kumari, S.; Annamareddy, S.H.K.; Abanti, S.; Rath, P.K. Physicochemical properties and characterization of chitosan synthesized from fish scales, crab and shrimp shells. Int. J. Boil. Macromol. 2017, 104, 1697-1705. [CrossRef]

11. Zhang, H.C.; Yun, S.Y.; Song, L.L.; Zhang, Y.W.; Zhao, Y.Y. The preparation and characterization of chitin and chitosan under large-scale submerged fermentation level using shrimp by-products as substrate. Int. J. Boil. Macromol. 2017, 96, 334-339. [CrossRef] [PubMed]

12. Mohanasrinivasan, V.; Mishra, M.; Paliwal, J.S.; Singh, S.K.; Selvarajan, E.; Suganthi, V.; Devi, C.S. Studies on heavy metal removal efficiency and antibacterial activity of chitosan prepared from shrimp shell waste. 3 Biotech 2013, 4, 167-175. [CrossRef] [PubMed]

13. Zhang, H.C.; Yu, H.N.; Chen, S.S. Production of chitin and chitosan using successive three-step microbial fermentation. J. Polym. Mater. 2017, 34, 123-127.

14. Zhang, H.C.; Yang, S.F.; Fang, J.Y.; Deng, Y.; Zhao, Y.Y. Optimization of the fermentation conditions of Rhizopus raponicas M193 for the production of chitin deacetylase and chitosan. Carbohydr. Polym. 2014, 101, 57-67. [CrossRef]

15. Tammineni, N.; Rasco, B.; Powers, J.; Nindo, C.; Unlu, G. Bovine and fish gelatin coatings incorporating tannins: Effect on physical properties and oxidative stability of salmon fillets. J. Food Chem. Nutr. 2014, 2, 93-102.

16. Weska, R.; De Moura, J.M.; Batista, L.; Rizzi, J.; Pinto, L.A. Optimization of deacetylation in the production of chitosan from shrimp wastes: Use of response surface methodology. J. Food Eng. 2007, 80, 749-753. [CrossRef]

17. Cai, J.; Yang, J.; Du, Y.; Fan, L.; Qiu, Y.; Li, J.; Kennedy, J.F. Purification and characterization of chitin deacetylase from Scopulariopsis brevicaulis. Carbohydr. Polym. 2006, 65, 211-217. [CrossRef]

18. Kaya, M.; Baran, T.; Erdogan, S.; Menteş, A.; Özüsağlam, M.A.; Cakmak, Y.S. Physicochemical comparison of chitin and chitosan obtained from larvae and adult Colorado potato beetle (Leptinotarsa decemlineata). Mater. Sci. Eng. C 2014, 45, 72-81. [CrossRef]

19. Gałkowska, D.; Długosz, M.; Juszczak, L. Effect of high methoxy pectin and sucrose on pasting, rheological, and textural properties of modified starch systems. Starch-Stärke 2013, 65, 499-508. [CrossRef] 
20. Qi, L.; Xu, Z.; Jiang, X.; Hu, C.; Zou, X. Preparation and antibacterial activity of chitosan nanoparticles. Carbohydr. Res. 2004, 339, 2693-2700. [CrossRef]

21. Bajaj, M.; Winter, J.; Gallert, C. Effect of deproteination and deacetylation conditions on viscosity of chitin and chitosan extracted from Crangon crangon shrimp waste. Biochem. Eng. J. 2011, 56, 51-62. [CrossRef]

22. Samar, M.M.; El-Kalyoubi, M.; Khalaf, M.; El-Razik, M.A. Physicochemical, functional, antioxidant and antibacterial properties of chitosan extracted from shrimp wastes by microwave technique. Ann. Agric. Sci. 2013, 58, 33-41. [CrossRef]

23. Luo, Q.; Wang, Y.; Han, Q.; Ji, L.; Zhang, H.; Fei, Z.; Wang, Y. Comparison of the physicochemical, rheological, and morphologic properties of chitosan from four insects. Carbohydr. Polym. 2019, 209, 266-275. [CrossRef] [PubMed]

24. Aguirre-Loredo, R.Y.; Hernández, A.I.R.; Morales-Sánchez, E.; Gómez-Aldapa, C.A.; Velazquez, G. Effect of equilibrium moisture content on barrier, mechanical and thermal properties of chitosan films. Food Chem. 2016, 196, 560-566. [CrossRef] [PubMed]

25. Fernández-Pan, I.; Maté, J.; Gardrat, C.; Coma, V. Effect of chitosan molecular weight on the antimicrobial activity and release rate of carvacrol-enriched films. Food Hydrocoll. 2015, 51, 60-68. [CrossRef]

26. Tolaimate, A.; Desbrières, J.; Rhazi, M.; Alagui, A.; Vincendon, M.; Vottero, P. On the influence of deacetylation process on the physicochemical characteristics of chitosan from squid chitin. Polymer 2000, 41, 2463-2469. [CrossRef]

27. Younes, I.; Hajji, S.; Frachet, V.; Rinaudo, M.; Jellouli, K.; Nasri, M. Chitin extraction from shrimp shell using enzymatic treatment. Antitumor, antioxidant and antimicrobial activities of chitosan. Int. J. Boil. Macromol. 2014, 69, 489-498. [CrossRef]

28. Hussain, R. Determination of degree of deacetylation of chitosan and their effect on the release behavior of essential oil from chitosan and chitosan-gelatin complex microcapsules. Int. J. Adv. Eng. Appl. 2013, 2, 4-12.

29. Knidri, H.; Dahmani, J.; Addaou, A.; Laajeb, A.; Lahsini, A. Rapid and efficient extraction of chitin and chitosan for scale-up production: Effect of process parameters on deacetylation degree and molecular weight. Int. J. Boil. Macromol. 2019, 139, 1092-1102. [CrossRef]

30. Hargono, H.; Djaeni, M. Utilization of chitosan prepared from shrimp shell as fat diluent. Indones. J. Chem. 2003, 5, 130-134.

31. Patria, A. Production and characterization of chitosan from shrimp shells waste. Aquac. Aquar. Conserv. Legis. 2013, 6, 339-344.

32. Cahyaningrum, S.E.; Amaria, A. Utilization of penaus monodon shrimp shell waste as adsorbent of cadmium(II) in water medium. Indones. J. Chem. 2010, 5, 130-134. [CrossRef]

33. Qin, Y.; Xing, R.; Liu, S.; Li, K.; Meng, X.; Li, R.; Cui, J.; Li, B.; Li, P. Novel thiosemicarbazone chitosan derivatives: Preparation, characterization, and antifungal activity. Carbohydr. Polym. 2012, 87, 2664-2670. [CrossRef]

34. Kumar, R.; Xavier, K.A.M.; Lekshmi, M.; Balange, A.; Gudipati, V. Fortification of extruded snacks with chitosan: Effects on techno functional and sensory quality. Carbohydr. Polym. 2018, 194, 267-273. [CrossRef] [PubMed]

35. Akpan, E.I.; Gbenebor, O.; Adeosun, S. Synthesis and characterisation of chitin from periwinkle (Tympanotonus fusatus (L.)) and snail (Lissachatina fulica (Bowdich)) shells. Int. J. Boil. Macromol. 2018, 106, 1080-1088. [CrossRef]

36. Pereira, M.A.V.; Fonseca, G.D.; Silva-Júnior, A.A.; Fernandes-Pedrosa, M.F.; Moura, M.D.F.V.D.; Barbosa, E.G.; Gomes, A.P.B.; Dos Santos, K.S.C.R.; Fernandes-Pedrosa, M.D.F. Compatibility study between chitosan and pharmaceutical excipients used in solid dosage forms. J. Therm. Anal. Calorim. 2014, 116, 1091-1100. [CrossRef]

37. Rao, V.; Johns, J. Thermal behavior of chitosan/natural rubber latex blends TG and DSC analysis. J. Therm. Anal. Calorim. 2008, 92, 801-806. [CrossRef]

38. Guinesi, L.S.; Cavalheiro, E. The use of DSC curves to determine the acetylation degree of chitin/chitosan samples. Thermochim. Acta 2006, 444, 128-133. [CrossRef]

39. Yen, M.T.; Mau, J.L. Selected physical properties of chitin prepared from shiitake stipes. LWT-Food Sci. Technol. 2007, 40, 558-563. [CrossRef]

40. Jung, W.J.; Kuk, J.H.; Kim, K.Y.; Park, R.D. Demineralization of red crab shellwaste by lactic acid fermentation. Appl. Microbiol. Biotechnol. 2005, 67, 851-854. [CrossRef] 
41. Rinaudo, M. Chitin and chitosan: Properties and applications. Prog. Polym. Sci. 2006, 31, 603-632. [CrossRef]

42. Julkapli, N.M.; Akil, H.M. X-Ray Powder Diffraction (XRD) studies on kenaf dust filled chitosan bio-composites. Proc. AIP Conf. Proc. 2008, 989, 111-114.

43. Schmitt, D.R.; Schmitt, D.R. Ultrasonic shear wave reflectometry applied to the determination of the shear moduli and viscosity of a viscoelastic bitumen. Fuel 2018, 232, 506-518. [CrossRef]

44. Flores, A.; Ania, F.; Baltá-Calleja, F.J. From the glassy state to ordered polymer structures: A microhardness study. Polymer 2009, 50, 729-746. [CrossRef]

45. Liu, Z.; Ge, X.; Lu, Y.; Dong, S.; Zhao, Y.; Zeng, M. Effects of chitosan molecular weight and degree of deacetylation on the properties of gelatine-based films. Food Hydrocoll. 2012, 26, 311-317. [CrossRef]

46. Hamdi, M.; Nasri, R.; Hajji, S.; Nigen, M.; Li, S.; Nasri, M. Acetylation degree, a key parameter modulating chitosan rheological, thermal and film-forming properties. Food Hydrocoll. 2019, 87, 48-60. [CrossRef]

47. Tang, Y.; Zhang, X.; Zhao, R.; Guo, D.; Zhang, J. Preparation and properties of chitosan/guar gum/nanocrystalline cellulose nanocomposite films. Carbohydr. Polym. 2018, 197, 128-136. [CrossRef]

48. Garcia, L.G.S.; Guedes, G.M.D.M.; Fonseca, X.M.Q.C.; Pereira-Neto, W.A.; Castelo-Branco, D.S.C.M.; Sidrim, J.J.D.C.; Cordeiro, R.D.A.; Rocha, M.F.G.; Vieira, R.S.; Brilhante, R.S.N. Antifungal activity of different molecular weight chitosans against planktonic cells and biofilm of Sporothrix brasiliensis. Int. J. Boil. Macromol. 2020, 143, 341-348. [CrossRef]

49. Chen, C.-Y.; Chung, Y. Comparison of Acid-Soluble and Water-Soluble Chitosan as Coagulants in Removing Bentonite Suspensions. Water Air Soil Pollut. 2010, 217, 603-610. [CrossRef]

50. Sun, Z.; Shi, C.; Wang, X.; Fang, Q.; Huang, J. Synthesis, characterization, and antimicrobial activities of sulfonated chitosan. Carbohydr. Polym. 2017, 155, 321-328. [CrossRef]

51. Gadkari, R.R.; Suwalka, S.; Yogi, M.R.; Ali, W.; Das, A.; Alagirusamy, R. Green synthesis of chitosan-cinnamaldehyde cross-linked nanoparticles: Characterization and antibacterial activity. Carbohydr. Polym. 2019, 226, 115298. [CrossRef] [PubMed]

52. Kong, M.; Chen, X.; Xing, K.; Park, H.J. Antimicrobial properties of chitosan and mode of action: A state of the art review. Int. J. Food Microbiol. 2010, 144, 51-63. [CrossRef] [PubMed]

53. Zhang, H.C.; Jung, J.; Zhao, Y.Y. Preparation, characterization and evaluation of antibacterial activity of different particle sizes of $\beta$-chitosan nanoparticles encapsulated catechins and catechins-Zn complex. Carbohydr. Polym. 2016, 137, 82-91. [CrossRef] [PubMed]

54. Nakayama, M.; Shigemune, N.; Tsugukuni, T.; Jun, H.; Matsushita, T.; Mekada, Y.; Kurahachi, M.; Miyamoto, T. Mechanism of the combined antibacterial effect of green teaextract and $\mathrm{NaCl}$ against Staphylococcus aureus and Escherichia coli O157:H7. Food Control. 2012, 25, 225-232. [CrossRef]

Sample Availability: Samples of the compounds are available from the authors.

(C) 2020 by the authors. Licensee MDPI, Basel, Switzerland. This article is an open access article distributed under the terms and conditions of the Creative Commons Attribution (CC BY) license (http://creativecommons.org/licenses/by/4.0/). 